\title{
Evaluating "WeSt Kalimantan CUlinary BoOK” AS A SUPPLEMENTARY BOOK FOR UNDERGRADUATE STUDENTS
}

\author{
Stella Prancisca ${ }^{1)}$, Ana Fergina ${ }^{2)}$ \\ ${ }^{1)}$ Universitas Tanjungpura, Pontianak, Indonesia \\ E-mail: stellaguru123@untan.ac.id \\ 2) Universitas Tanjungpura, Pontianak, Indonesia \\ E-mail: anafergina@untan.ac.id
}

\begin{abstract}
The present research believes that teaching materials which promote Indonesian traditional heritages should be available for students both inside and outside the classroom. For this reason, the research aims to preserve the presence of local cultures in the mid of English culture's popularity by developing a book which contains aformentioned topics. The outcome of this empirical research is a textbook used as media for extensive reading in the student's pleasure time. Using the ADDIE approach, this research collected data from several undergraduate students currently studying at a state university in Indonesia. The students were requested to read the West Kalimantan Culinary Book and share their ideas on what they have just read. In addition, the book was evaluated by experts from linguistic and cultural fields. The student's feedbacks were very useful as they would reflect a potential user's view in the future. Meanwhile, evaluations from experts helped us verify if the book was developed properly. Results indicated that readers responded to this culinary book positively. The book was considered helpful and unique as it was written in the English language. Since the book was aimed for extensive reading materials, we also checked and confirmed that this book followed the principles of extensive reading expressed by Day and Bamford (2002). To conclude, the research indicates its limitation particularly in terms of generalisability and provides suggestions for further research in order to improve the instruments of the data collection.
\end{abstract}

Keywords: Extensive Reading; ADDIE; Local Cultures

\section{INTRODUCTION}

Nowadays, English language mastery plays a vital role for students in higher educations. Good command in the English language may increase their selling points after graduation and make them stand out among other job seekers. In particular, ASEAN countries have regulated a free-trade system where it opens opportunities for professional workers outside Indonesia to have a job in Indonesia. The English language then is a must in order to keep a chance to work at prestigious companies. In addition, the language can help the students to seek job opportunities outside Indonesia once they finished their study.

The Indonesian government has promoted progressive programs to achieve that. The government keeps evaluating the national curriculum in secondary school levels. Publishers are also in the race to design an English language textbook which is internationally standardized. The publishers hope that book users can feel an authentic atmosphere of language learning as if they were in Englishspeaking countries. Examples written in the textbooks frequently refer to the country's contexts and settings.

These actions must be appreciated on one hand. However, on the other hand, a concern should be given as students possibly receive too much foreign exposure. Gradually, the students may feel that western cultures (where the English language is widely spoken) will look better and more prestigious than their own cultures. This is true particularly when local cultures are not proportionally embedded in student's textbooks (Hermawan \& Lia, 2012; Pashmforoosh $\&$ Babaii, 2015; Yuen, 2011). As a result, the awareness of the local cultures could decline.

For that reason, this research initiates to conduct research with an English language book as an outcome. The book combines two key elements of English language teaching in the classroom namely local culture and the language itself. The book is named "Kalimantan Barat Traditional Culinary Book". As the title suggests, the book focuses on one aspect 
of the culture, i.e. dish or food that characterizes communities in West Kalimantan (Kalimantan Barat). It is written in English because it aims to reach undergraduate students who are currently studying English. Nevertheless, the book is also suitable for wider scale users for example library visitors, school students, or other communities. Additionally, the book may be useful as information for tourists who visit West Kalimantan for the first time or foreigners who are interested in traditional dishes of the province.

Regardless of the importance of culture-based books for English language students, up to present, research connecting local cultures and English language teaching in Indonesia remains insufficient. The existing research tends to separate the two elements and is conducted in primary and secondary levels. For instance, research carried out by Murni and Wati (2013) in Riau selects primary school level as their core focus. More recently, Yamin, Mu'in, and Arini (2016) try to develop language learning activities which integrate the notion of local wisdom. However, the research focuses on students at the secondary level.

More specific research to West Kalimantan is even more limited. Until now, there are just two research papers which are identified to discuss West Kalimantan cultures in English language teaching. These papers are graduate theses which are only published internally in the university. However, the results of the research remain captivating to elucidate. Kasmawita (2015) for example successfully develops a learning material called ALCON-PRO. This is a project-based material allowing the students to explore and trace local cultures which exist in Singkawang. This model is claimed successfully to reintroduce old cultures or simply as a means to remember the student's traditional cultures.

Another interesting result is reported by Aprisama (2015). He modifies people's traditional game named Lem Lem Tak to become a thrilling game that students can play in the classroom. The research is conducted in a primary school in Singkawang. Having examined to small and big groups, he is convinced that this game is decent to increase communication among students. The students also have more chances to use the target language that they are studying. Interestingly, this game is physically engaged. Thus, it helps the students to actively participate in the classroom and increase their motivation and friendship. This research successfully gains student's interest to play the old game that used to be very popular.

As mentioned earlier, English-written books which embed local cultures are limited. As a consequence, textbooks disseminated to students often promote information about foreign cultures. If local cultures appear in the book, they are presented in small parts of the book. A study from Hermawan and Lia (2012) criticizes how local information is presented in student's textbooks. They claim that information which introduces local content barely appears in the books they are reviewing. If they can find it, the information is surficial. For instance, local information is only used for names or places without providing further promotion. Therefore, we conclude that books which explore local cultures are urgently needed.

We observe three gaps from previous research we mention before. First, existing research merely focuses on school levels. Second, research published in journals is conducted outside West Kalimantan. Research which raises West Kalimantan cultures is extremely scant. Research existed today is in the form of graduate theses. Finally, a book where local cultures become the main content frequently offers a massive promotional advantage to West Kalimantan.

Research in the past has alarmed academicians to develop teaching materials for student's enrichment in English language course. The teaching material can take in many forms such as textbook, DVD, video, worksheet, or even food packaging (Tomlinson, 2011). Importantly, it should cover key elements of teaching materials. The elements include a linguistic aspect (instructional), an experiential aspect when using the language (experiential), stimulant aspect to use the target language (elicitation), as well as a facilitative aspect for them to explore new things (exploratory). The book that we are developing should be in line with these needs. A need analysis to student's needs was carried out in the first stage of this research. It went through several stages namely analysis, design, and development. This year, this research verifies if the results of the analysis appear when used in the classroom. It investigates if the book has fulfilled linguistics, experimental, elicitation, and exploratory aspects.

Additionally, this research attempts to evaluate if the book can really be used as an alternative for Extensive Reading (ER) in the English language classroom. Day and Bamford (2002) provides ten principles of extensive reading. According to them, ER material should meet several criteria. For istance, the materials should be easy, have wide reading variations, encourage students to read as much as possible, promote reading for pleasure, use reading as its own reward, be quick in reading speed, be individual and silent, and encourage teachers as a guide and a model for the students. In 2015, Day provided an extending version of Extensive Reading. He figured out that a number ER programs undertaken since 1998 documented several variations in practices. He made a continuum of so-called Pure ER to programs which adopted all principles of ER and Modified ER to those that adopted many principlese. The continuum went on ER Light if the program only some of the principlse to Fringe ER where none of the principles were employed. The continuum, unfortunately, did not mention the exact boundary of Modified ER and ER Light and it might cause confusion since people might have different perceptions to count "many" and "some".

As an out-of-class language program, ER is considered powerful enough to accelerate student's English language competence. ER has been carried out as a scheduled program in several countries and is believed to promote student's reading skills including in the forms of reading speed (He, 2014; Iwahori, 2008), durability (Renandya \& Jacobs, 2016), reading motivation (Mori, 2015; Renandya \& 
Jacobs, 2016), and vocabulary enhancement (Liu \& Zhang, 2018). Nevertheless, Maley (2011) reminded us that every learning situation was unique, depending on where the learning process took place. He suggested considering the following issues before developing reading material. First, the reading material should adopt local content. Xie (2005) claimed that one of the challenges of Asian students to comprehend an English-written text was the lack of local content in the text. Thus, by adopting topics which arise from the student's daily life, it is hoped that the text become easier to understand. After that, the book is flexible depending on the student's needs. Next, it should encourage the use of technology. Finally, the books should use content-based learning. Therefore, the book that we are developing refers to Maley's advice.

\section{Methodology}

This section discusses methods that researchers employ to evaluate West Kalimantan Traditional Culinary Book. Having completed the first stage of the research in 2017, the book is implemented to its direct users this year. After that, the book is evaluated by using specific method and instruments in which follow the expert's standards. As the previous research, this year we use ADDIE (Analysis, Design, Development, Implementation, and Evaluation) approach as the main reference.

\section{A. Research Context and Participants}

This research was conducted at a language center in a state university in West Kalimantan. The language center was re-elected this year because it still represented the biggest language center in the province. The language center's main responsibility is to prepare students who take the TOEFL test and to handle English language courses in faculties in the university. The university has nine faculties which are very diverse in terms of knowledge background. Data collected from this research would be very useful as it reflected ideas from different perspectives. The participants were selected from the first-year students considering the access to gain permission for these students tended to be easier.

\section{B. Procedures of Data Collection}

In this stage, students were requested to read West Kalimantan Traditional Culinary Book. They were allowed to bring the book home and read in their pleasure time. They may leave their reading unfinished and continue reading the book at any time they like. They were also requested to take notes on their reading progress. They noted the number of pages that they can read in a certain period of time. We also gave the book to expert users such as a public figure who had a vast experience in West Kalimantan Culinary. Another chance was also given to linguistics experts to verify if the language used in the book had been appropriate or not.

After that, data was collected which consisted of user's and expert's views towards the book. For students, their feedbacks were useful as they would become direct users.
The researchers would notice which part that the users like and do not like from the book. Meanwhile, experts provided useful and objective assessments regarding technical issues on how this book was developed.

\section{Instruments}

As mentioned earlier, data in this research was collected from various means. In the implementation stage, participants must read West Kalimantan Traditional Culinary Book. The reading process could take place in or out of the classroom. Meanwhile, in the evaluation stage, the researchers employed questionnaires distributed to students and experts. The questionnaires comprised of closed- and open-ended questionnaires. The experts involved in this research were from linguistic and cultural fields of knowledge. The experts were selected according to professional competences that had a vast experience in their fields to assure the validity of the data.

\section{Data Analysis}

This research used a content analysis to approach the data. It consisted of several coding processes. This technique allowed the researchers to obtain well-organised information and facilitated us to interpret the data easier. Results of the interpretation then were confirmed by evaluations from the selected experts. The book was evaluated by the lens of extensive reading principles adapted from Day and Bamford (2002). They proposed ten principles of extensive reading. However, in this research we did not select all items but only six in order to adjust to the initial goal of the research. We also added one more item i.e. the reading materials have a local wisdom content" because this books used local culture as its main focus. The completed principles of extensive reading evaluated in this research can be seen in Table I.

TABLE I

EXTENSIVE READING PRINCIPLES

\begin{tabular}{ll}
\hline No & Item Description \\
\hline 1 & The reading materials are easy \\
2 & Learners read as much as possible \\
3 & The purpose of reading is usually related to pleasure, \\
& information, and general understanding. \\
5 & Reading is its own reward. \\
6 & Reading speed is usually faster rather than slower. \\
7 & the reading in individual and silent \\
\hline
\end{tabular}

\section{RESULTS AND DISCUSSION}

\section{A. Close-ended Questionnaires}

This section presents empirical data collected from June to August 2018. As mentioned earlier, the research used questionnaires. The questionnaires were shared with several students who have read West Kalimantan Culinary book. Other questionnaires were also given to experts in culinary of West Kalimantan. Both questionnaires consisted of close and open-ended types. For close-ended questionnaires, the 
option "YES" was rated 1 point and option "NO" were scored 0 point. After that, all participants and expert were provided with open-ended questionnaires. It aims at strengthening claims made from the previous questionnaires. The results of the questionnaires is displayed in Table II.

TABLE II

OVERALl RESUlTS OF CLOSE-ENDED QUESTIONNAIRES (STUDENTS)

\begin{tabular}{|c|c|c|c|}
\hline No. & $\begin{array}{l}\text { Questions } \\
\end{array}$ & $\%$ & ER Principles \\
\hline \multirow[t]{2}{*}{1} & Do you think that West & & \\
\hline & $\begin{array}{l}\text { Kalimantan Culinary } \\
\text { book is easy to } \\
\text { understand? }\end{array}$ & $100 \%$ & 1 \\
\hline 2 & $\begin{array}{l}\text { Is the book useful for } \\
\text { you? }\end{array}$ & $100 \%$ & 3 \\
\hline \multirow{2}{*}{$\begin{array}{l}3 \\
4\end{array}$} & Is it an interesting book? & $100 \%$ & 3 \\
\hline & $\begin{array}{l}\text { Does the book encourage } \\
\text { your willingness to keep } \\
\text { reading in English } \\
\text { language? }\end{array}$ & $90 \%$ & 3 \\
\hline 5 & $\begin{array}{l}\text { Do you realize that you } \\
\text { are learning English while } \\
\text { reading the book? }\end{array}$ & $30 \%$ & 4 \\
\hline 6 & $\begin{array}{l}\text { Do you think that this } \\
\text { book helps accelerate } \\
\text { your reading speed? }\end{array}$ & $80 \%$ & 5 \\
\hline 7 & $\begin{array}{l}\text { Does the book help you to } \\
\text { start reading } \\
\text { independently? }\end{array}$ & $100 \%$ & 6 \\
\hline 8 & $\begin{array}{l}\text { Does the book help you } \\
\text { recognize local cultures of } \\
\text { West Kalimantan, } \\
\text { especially in culinary and } \\
\text { traditional culture? }\end{array}$ & $100 \%$ & $3 \& 7$ \\
\hline 9 & $\begin{array}{l}\text { Does the book grow your } \\
\text { love toward local culture } \\
\text { in West Kalimantan, } \\
\text { especially regarding local } \\
\text { dishes? }\end{array}$ & $100 \%$ & 7 \\
\hline 10 & $\begin{array}{l}\text { Does the book encourage } \\
\text { you to try the food that } \\
\text { you have just read? }\end{array}$ & $90 \%$ & 4 \\
\hline 11 & $\begin{array}{l}\text { Does local culture } \\
\text { embedded in this book } \\
\text { facilitate you in } \\
\text { comprehending the } \\
\text { content rather than those } \\
\text { which do not contain local } \\
\text { cultures? }\end{array}$ & $70 \%$ & 7 \\
\hline
\end{tabular}

Based on the data above, the participant's responses for all items reached more than $50 \%$. It means that in general almost all participants in this context highly agree that the book is beneficial and interesting for the readers. Some questions such as no 1, 2, 3, 7, 8, and 9 even received maximum scores from the participants. It shows us that the participants are aware that the book is easy to understand so that it makes the book interesting and becomes beneficial. All participants in this research agreed that this book could be used as a starting media to ignite reading habit among the students. This finding confirms earlier studies such as Mori (2015) who claimed that student's motivation to start and keep reading in English was determined by an interesting and comprehensible reading text. When the students read a text that they could understand, Renandya and Jacobs (2016) believed that the students could enjoy and follow their reading flows. Thus, their motivation and confidence will increase. Moreover, local cultures embedded in the book helped them recall their local cultures and grow their love towards the local cultures. These local-culture topics have been heard or read by the students in their native language resources. Once the topics were translated into English, the students already had a prior knowledge towards what they would be reading. Thus, it leads to better understanding, yet remains challenging due to its language nature.

Some other questions such as 4, 6, 10, and 11 still gained high scores although they did not reach maximum ones. Question 11 had the lowest score by $70 \%$. According to the participants, local cultures embedded in the book did not really help them in comprehending the text. Finally, although question no 5 (see table 1) seemed to indicate a negative result at a glance, i.e. $30 \%$, the question should be inferred reversely. The lower the score gained from the participants, the better it was because it implied that the students really enjoyed reading the book. It was probably because the plot was interesting or the language was easy so that they should not open the dictionary frequently. Because the participants enjoyed the book so much, they did not even realize that they were learning new vocabularies and growing their new habit of reading in the English language. In this extent, "extensive reading is not usually followed by comprehension questions. It is an experience complete in itself (Day \& Bamford 2002, p. 138). Enjoyment in reading is much more appreciated which eventually disregard the presence of comprehension questions. The more they enjoy the reading, it indicates the depth of their involvement towards their reading. Thus, the focus is shifted to gain reading enjoyment and general comprehension rather than searching detailed information or facts in the text.

\section{B. Open-ended Questionnaires}

For questions no 12, most participants could complete reading the book within 3 hours. Two participants however finished it in more than 3 hours i.e. 2 and 3 days. This is possible because they did not finish it in one-time reading but rather they stopped several times and returned to read the book in the other time. It could be confirmed by a question no 13 where several participants spent $12-15$ pages at once. It means that they only read some parts of the book, not the entire book.

Meanwhile, for question no 14, a number of participants answered that Bingke Berendam was their favorite part which was then followed by Kerupuk Basah and other foods. Some participants also admitted that they liked the pictures of the book and the recipes. Finally, for question 15, participants added that picture and content were the strength of the book because they were interesting and could promote West Kalimantan Culture. Gunaydin and Karamete 2016) correctly supported this finding by pointing out that teaching materials developers should pay attention on the 
materials layour and appearance. They should be able to design materials which are "pleasing to the eye and reflecting visual integrity" (p.118). Thus, Participant 1 mentioned that "this book is not only entertaining but also can be used as an educational facility".

Some participants provided some feedbacks towards this book. Some of them were the inclusion of estimated price for each food. A story behind the food could be also interesting to add. Some others mentioned that there was a need for glossaries for names and types of plants like Pakis and Daun Kesum "because these plants have specific terms in the English language which may be unfamiliar for beginner learners" (Participant 2).

\section{Evaluations from Experts}

Besides students, feedbacks from experts were also requested to assess how this book was developed in terms of its content and language. For the linguistics aspect, we asked for help from a native speaker which had a vast experience in English language teaching including material development. He is currently teaching at a state university in the US. Feedbacks that we received from this expert were language appropriateness used in this book. This was to check if the vocabulary and sentence structures were appropriate for English-speaking readers.

After that, we requested opinions from culinary experts of West Kalimantan to evaluate its cultural content. This expert had years of experience in West Kalimantan Culinary. $\mathrm{He}$ was a founder of the Center of West Kalimantan Culinary Studies. Results revealed that the West Kalimantan Culinary Book was easy to understand and successful to provide pictures of typical local culinary. He also agreed that the book could potentially encourage the readers to try the food and make the food at home. It could help the local government in promoting traditional culinary of West Kalimantan. However, he made few notes for the last question that several aspects such as procedures and recipes were slightly different. This is possible because of the difference between regions and cultures spreading in regencies of West Kalimantan.

\section{Evaluations for Extensive Reading Principles}

Day and Bramford (2002) expressed ten principles of Extensive Reading (ER) which were then adapted to measure if the book that we designed had met these principles. As mentioned earlier, Day (2015) extended his explanation on ER program where all principles were not necceraly followed to run the ER program (see page 3-4) . The researchers attempted to fulfill all criteria although finally, we decided to only use six principles and add one more principle. The additonal principle was related to the cultural aspect (see methodology). Therefore, it is reasonable to assume that the present research falls into the category of Modified ER (many principles) or ER Light (some principlese) in the Day's extended ER version. In order to check if the book was in line with these principles, here are the elaborations of each principle.
1) The reading material is easy

One of the characteristics of extensive reading is that students choose a book which is at or under their level. One of the reasons is to prevent them from encountering too many difficult vocabularies which potentially distract the flow of the reading. In addition, it could help them avoid looking up dictionary very often. Day and Bamford (2002) claimed that difficult reading level could decline student's motivation in reading because the students can easily feel bored and may not enjoy what they are reading. In contrast, Renandya and Jacobs (2016) argued that a good choice of reading materials which were suitable to the student's level might even help the students boost their confidence and motivation in reading.

In this research, all participants mentioned that this book was easy to understand. It was also supported by the fact that they could finish reading the book under three hours. This was in line with the findings of Ying-Chun, Chern, and Reynolds (2018). They suggested that teachers should ensure the student's reading level before asking the students to read extensively. Thus, this book was intentionally designed for a beginner level. If the students encountered unfamiliar words, they could maximize lists of vocabularies as guidance which they can find on the same page.

2) Students read as much as possible

Reading as much as possible means to give a huge amount of exposure to the students either in terms of genres or the book volumes. Because the students only read one book in this research, we measured this aspect from the number of pages that students could read. In the research, all participants successfully finished reading this 44-page book.

3) The purpose of the reading is usually related to pleasure, information, and a general understanding

Reading a book is not a common practice for students in Indonesia, moreover, for English-written books. Therefore, the book that we designed should be interesting in content and layout to attract the student's attention to read. The book should be easy to understand so they can follow the storyline of the book and enjoy the reading. This West Kalimantan Culinary book was in line with the principles explained by Day and Bamford (2002) where the book should be informative. Additionally, most of the participants in this research agreed that this book was not only entertaining but capable of adding new knowledge for the readers.

This book was designed following the principle above. Participant 1 concluded this by saying that "this book was not only entertaining but also can be used as an educational facility", something that is called as "the real-world purposes of reading" (Iwahori, 2008, p.71). Students who read this book can gain new information regarding their surrounding cultures. Bingke Berendam may not be new for them, but the ways to cook it could be completely novel. 
4) Reading is its own reward

According to Day and Bomfard (2002), the best reward of extensive reading was the joy of reading itself. A pleasant experience when reading (unlike in the classroom where they often read above their level) make them enjoy every words and page of what they read. Almost all participants (70\%) even did not realize that they were studying the English language.

\section{5) Reading is usually faster}

Another characteristic of extensive reading is the speed in reading. Most of the participants felt that their speed increased and they could complete their reading in less than three hours. One of the potential factors is they barely open dictionary. Day and Bamford (2002) suggest skipping vocabularies that they perceive difficult. This is also supported by previous scholars (He 2014; Iwahori 2008) whose participants taking part in their extensive reading research recorded an increase in reading fluency.

\section{6) Reading is individual and silent}

Day and Bamford (2002) posit that extensive reading is an individual activity. It teaches the students to not worry if their classmates already finish reading their books or not. Every student has their own speed. It is not wondering then if participants take a different range of time to read this culinary book. Some students can finish it in less than half an hour while the others need days. Thus, to accommodate this, when the data was collected they were requested to read individually in separate places.

7) Reading material contains local cultures

This research follows Xie's (2005) recommendation by adding an extra question as an indicator which makes the book typical West Kalimantan book. Local content embedded in the book was considered successful to attract attention from the readers. They become more familiar and wish to try cooking the food at home too. However, culinary expert suggests that the information should be presented in three main groups such as meals (Asam Pedas), light meals (Bubur Pedas), and snacks (Bingke Berendam). The purpose is to inform new readers about the description of the food and when the food is normally served.

\section{CONCLUSIONS}

West Kalimantan Culinary Book was designed to introduce local cultures in West Kalimantan. It also aimed at fulfilling the needs of reading materials which were written in the English language. In general, data of the research indicated that readers responded to the book positively. One of the comment revealed that the book helped the participants figured out information about West Kalimantan in a different manner. Additionally, they admitted that the book was easy and interesting.

However, the results of the research should be interpreted approximately. First, the numbers of participants were limited. 10 students who read and provided feedback for this book were not enough to generalise the results across contexts in Indonesia. However, the data remains useful for regions which share a similar context as this research. This is especially for students who have an English course at a higher education or those who are at the beginner level. Finally, an in-depth data instrument is also needed such as observations and interviews because this research only employed a self-report instrument (questionnaires).

\section{REFERENCES}

Aprisama, S. (2015). Teaching Technique Development for Elementary School Students in Teaching Listening and Speaking: A Development Research at SD Negeri 17 Singkawang Tengah. Unpublished Master's Dissertation. Pontianak, Universitas Tanjungpura.

Day, R. \& Bamford, J. (2002) Top ten principles for teaching extensive reading. Reading in a Foreign Language, 14(2), 136-141.

Day, R. R. (2015). Extending extensive reading. Reading in a Foreign Language, 27(2), 294-301.

Gunaydin, S., \& Karamete, A. (2016). Material Development to Raise Awareness of Using Smart Boards: An Example Design and Development Research. European Journal of Contemporary Education, 15(1), 114-122. https://doi.org/10.13187/ejced.2016.15.114

He, M. (2014). Does Extensive Reading Promote Reading Speed? The Reading Matrix, 14(1),16-25.

Hermawan, B., \& Lia, N. (2012). Traces of Cultures in English Textbooks for Primary Education. Indonesian Journal of Applied Linguistics, 1(2), 49. https://doi.org/10.17509/ijal.v1i2.84

Iwahori, Y. (2008). Developing Reading Fluency: A Study of Extensive Reading in EFL. Reading in a Foreign language, 20(1), 70-91.

Kasmawita. (2015). Developing ALCON-PRO in English Teaching and Learning for Senior High School 1 Singkawang: The Implementation of Curriculum 2013. Unpublished Master's Dissertation. Pontianak, Universitas Tanjungpura.

Liu, J., \& Zhang, J. (2018). The Effects of Extensive Reading on English Vocabulary Learning: A Metaanalysis. English Language Teaching, 11(6), 1-15. https://doi.org/10.5539/elt.v11n6p1

Maley, A. (2011). Squaring the Circle - Reconciling Materials as Constraint with Materials as Empowerment. In B. Tomlinson (Ed.), Materials Development in Language Teaching. Cambridge: Cambridge University Press.

Mori, S. (2015). If you build it, they will come: From a "Field of Dreams" to a more realistic view of extensive reading in an EFL Context. Reading in a Foreign Language, 27(1), 129-135.

Murni, D., \& Wati, R. (2013). Pembelajaran Bahasa Inggris berbasis kearifan local. Master's Dissertation. Universitas Maritim Raja Ali Haji, Tanjungpinang.

Pashmforoosh, R., \& Babaii, E. (2015). Whose Culture and How Far? Culture Presentation in Current Business 
English Textbook Series. Journal of Teaching in International Business, 26(3), 216-236. https://doi.org/10.1080/08975930.2015.1083514

Renandya, W. A., \& Jacobs, G. M. (2016). Extensive reading and listening in the L2 classroom. In W. A. Renandya \& P. Handoyo (Eds.), English Language Teaching Today (pp. 97-110). New York, NY: Routledge.

Tomlinson, B. (Ed.). (2011). Materials development in language teaching. Cambridge University Press.

Xie, X. (2005). The Influence of Schema Theory on Foreign Language Reading Comprehension. The English Teacher, 34(1), 67-75.

Yamin, M., Mu'in, F., \& Arini, D. N. (2016). Kajian rencana pelaksanaan Pembelajaran Bahasa Inggris Blocal Tingkat SMPN di Kota Banjarmasin. Universitas Lambung Mangkurat, Banjarmasin.

Ying-Chun, S., Chern, C. L., \& Reynolds, B. L. (2018). Bringing extensive reading and reading strategies into the Taiwanese junior college classroom. Reading in a Foreign Language, 30(1), 130.

Yuen, K.-M. (2011). The representation of foreign cultures in English textbooks. ELT Journal, 65(4), 458-466. https://doi.org/10.1093/elt/ccq089. 